\title{
Improved adherence to anti-retroviral therapy among traditionalists: reflections from rural South Africa
}

\author{
Christopher Burman ${ }^{1}$, Marota Aphane ${ }^{2}$
}

\begin{abstract}
1. University of Limpopo, Rural Development and Innovation Hub, affiliated to the Turfloop Graduate School of Leadership.

2. University of Venda, Department of Research and Innovation.
\end{abstract}

\begin{abstract}
Background: Medical pluralism is common place in sub-Saharan Africa. The South African pluralistic health care environment is varied and includes traditionalist beliefs relating to the efficacy of African traditional medicine. Prior research indicates that traditionalism is associated with delays in testing for HIV and treatment interruption. Despite numerous reports about this in South Africa, there is a paucity of documented strategies to counter this trend.

Objectives: To develop a strategy to reduce the impact of non-adherence to antiretroviral therapy among traditionalists in Waterberg district, Limpopo Province, South Africa.

Methods: Qualitative information was elicited from five face-to-face, dual moderated, semi-structured homogenous group discussions. The groups comprised of 50 purposively selected, rurally based, mixed gender traditionalists living with HIV. Grounded theory was applied to analyse qualitative findings that emerged from the group discussions.

Findings: Self-reported increases in adherence to anti-retroviral therapy and a reduction in internalised stigma by the respondents. Both are attributed by the respondents to disease causation differentiation from a traditional explanation to an allopathic explanation.

Conclusion: A nascent strategy has been developed which is contributing to improved adherence and a reduction in internalised stigma among traditionalists living with HIV in Waterberg district, South Africa.

Keywords: HIV and AIDS; internalised stigma; makgoma; medical pluralism; 'origins of HIV'.

DOI: https://dx.doi.org/10.4314/ahs.v19i1.15

Cite as: Burman C, M A. Improved adherence to anti-retroviral therapy among traditionalists: reflections from rural South Africa. Afri Health Sci. 2019;19(1). 1422-1432. https://dx.doi. org/10.4314/ahs.v19i1.15
\end{abstract}

\section{Introduction}

This article reports on findings that relate to a community-university pilot partnership which began in 2014 that is focusing on HIV and AIDS in the Waterberg district, Limpopo Province, South Africa. The pilot is an action research initiative which comprises three phases. The first phase (2014-2015) was designed to; (1) determine the aims and objectives of the community-university partnership — which included improving adherence to anti-retroviral therapy (ART) among traditionalists living with

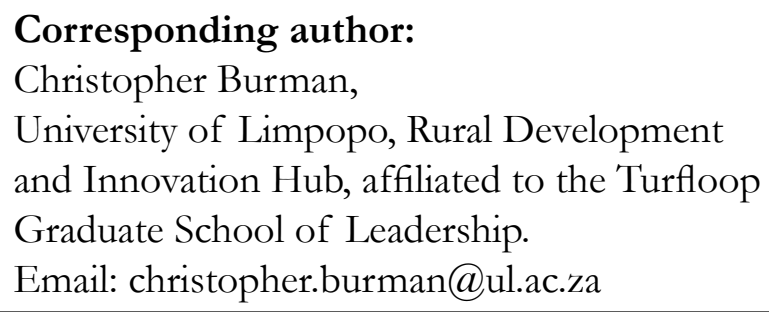

HIV, and (2) identify action themes that would become the focus of phase two. The second phase (2016 - 2017) involved transforming the action themes into educational heuristics in order to improve adherence to ART which is the focus of this article. The third phase (20172018) is designed to consolidate and share the findings with both civil society and the academic community as a foundation for future collaborations.

In Phase One, three action themes were identified using axial coding. The action themes were: the 'origins of HIV'; the 'viral load' and that — if ART is adhered to HIV is a chronic disease, not a 'death sentence'. 1:84. These findings were used as a foundation for phase two. In order to explain the process that was applied to improve adherence to ART in phase two, the following information is provided; (1) background information about the partnership; (2) the importance of adhering to ART; (3) how

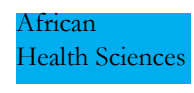

(C) 2019 Burman et al. Licensee African Health Sciences. This is an Open Access article distributed under the terms of the Creative commons Attribution License (https://creativecommons.org/licenses/BY/4.0), which permits unrestricted use, distribution, and reproduction in any medium, provided the original work is properly cited. 
medical pluralism has been shown to have an adverse impact on treatment seeking practices and one exemplar of this called 'makgoma', and (4) how the action themes were developed into social practices by the community partner. This background information is followed by the method, findings, discussion and conclusion.

\section{Background information about the partnership}

The partnership is between the University of Limpopo (UL) and a not for profit organisation that works with people who are infected or affected by HIV and AIDS called the Waterberg Welfare Society (WWS) ${ }^{2}$. WWS' Education and Awareness Department - comprised of two female nurses, a male school peer educator and a female child support worker - and the Rural Development and Innovation Hub (UL) have been the drivers of activities in the field. The Education and Awareness Department is primarily responsible for outreach activities among neighbouring communities in order to increase awareness about HIV and AIDS in ways that makes sense to those rural communities. The findings from phase one indicated that adherence to ART and medical pluralism would become relevant components of phase two ${ }^{1}$.

\section{The relevance of adhering to ART}

Strict adherence to ART significantly reduces mortality and morbidity associated with HIV-1 infection, ${ }^{3}$ as well as the chances of HIV transmission ${ }^{4}$. It has been estimated that the global coverage of ART was $46 \%$ in 2015 which resulted in a $26 \%$ reduction in annual HIV related deaths ${ }^{5}$. In South Africa, of the estimated 7.02 million people living with HIV, approximately 3.7 million (53\%) are on $\mathrm{ART}^{6}$.

Non-adherence to ART produces multiple challenges ranging from individual risk of developing HIV related infections, downward transmission of HIV and drug resistance ${ }^{7}$. In South Africa, non-adherence to ART of patients twelve months after they were initiated on ART in 2013 ranges from 21.4\% (North West Province) to $34.4 \%$ (Limpopo Province) at 12 months - representing a national average of $27 \%$ - which increases, nationally, to almost $50 \%$ at five years ${ }^{8}$. Ecological factors that are associated with non-adherence to ART include long travel distances and commensurate transport costs to health care facilities, household income, housing, gender, food security, employment status, family relationships, sub- stance abuse, crime, and violence - all of which have been documented extensively ${ }^{9-12}$. There is also evidence that medical pluralism adversely influences adherence at global $^{13}$, sub-Saharan ${ }^{14}$ and South African scales ${ }^{15}$. The South African National AIDS Council (SANAC) has also reported that the use of alternative, or traditional, medicines is one factor that contributes to the high levels of non-adherence in Limpopo Province ${ }^{16}$.

\section{Medical pluralism in South Africa}

In 2002 the World Health Organization (WHO) reported that $80 \%$ of people living in sub-Saharan Africa use traditional medicines ${ }^{17}$. Subsequent reports from South Africa suggest a contemporary, localised, figure closer to 50\%: Limpopo Province (study sample size reported on: $\mathrm{n}=240)^{18}$ and Kwa-Zulu Natal Province (study sample size reported on: $n=618)^{19}$. It is also estimated that there are 200,000 registered traditional health care practitioners treating 27 million people in South Africa ${ }^{20}$ — but this may be an under-estimation as many traditional health care practitioners are not registered ${ }^{21}$.

Whilst there is evidence that the traditional health care sector remains a 'valid and necessary' cultural component of sub-Saharan Africa's health care system, ${ }^{22: 67}$ there are unintended consequences that sometimes emerge from the convergences of the traditional and allopathic health care systems ${ }^{23}$. The unintended consequences emerge because many South Africans 'are able to switch between such health-worlds .... [and often] are able to straddle [the] two health-worlds simultaneously ${ }^{314.4}$ which can adversely influence treatment seeking practices.

\section{Treatment seeking practices and disease causation}

In the context of HIV, disease causation is a historically recognised phenomenon that influences treatment seeking practices. The relevance of disease causation being a determinate of how to treat symptoms corresponds with broader literature relating to the philosophical aspects of medical pluralism. ${ }^{24.25}$ In the context of HIV, the pluralistic South African health care environment is influenced by traditionalist beliefs (people that believe in the effectiveness of African traditional medicine) ${ }^{15}$ conspiracy theories (HIV and AIDS was invented by whites to control blacks) ${ }^{26}$ and Christian theology (HIV and AIDS was sent by God to punish immoral sexual behaviour) ${ }^{27}$ which converge with the biomedical health care system in variable ways. 
Whilst the opportunities provided by the South African biomedical health care system significantly reduces mortality and morbidity associated with HIV-1 infection, ${ }^{8}$ the convergences of the different beliefs in disease causation can have unintended, adverse impacts on both testing and treatment $\mathrm{t}^{14}$. One localised manifestation of an unintended consequence of medical pluralism on the HIV and AIDS epidemic in South Africa relates to a phenomenon that Sotho-Tswana speaking traditionalists call 'makgoma'.

\section{Makgoma}

Makgoma is an expression that is recognised by Sotho-Tswana speaking traditionalists ${ }^{28}$ that has been documented for over four decades ${ }^{29}$. Makgoma represents symptoms that are similar to HIV related co-infections which traditionalists associate with 'ritual defilement'. For traditionalists, ritual defilement occurs when an individual breaks with a traditional code of conduct and fails to observe specific cultural practices to rectify the transgres$\operatorname{sion}^{30}$. The failure to rectify the transgression results in 'contamination' of the body that is manifest in physical symptoms called makgoma ${ }^{31: 942}$. Quoting a representative of the National House of Traditional Leaders, a report in a popular South African newspaper called the Sowetan provides an exemplar of the similarities between the symptoms of HIV co-infections and makgoma ${ }^{32}$ :

'Culturally, we believe that you have makgoma (dirty blood) if your lover passes away, and if you don't get proper cleansing and rituals, anyone you sleep with will get so sick, and even have the same symptoms as someone with full-blown AIDS. So it is imperative to follow the correct rituals' (parenthesis in original, emphasis added).

Sotho-Tswana is a common language in Free State Gauteng, Limpopo, Mpumalanga and North West Provinces, Figure 1.)

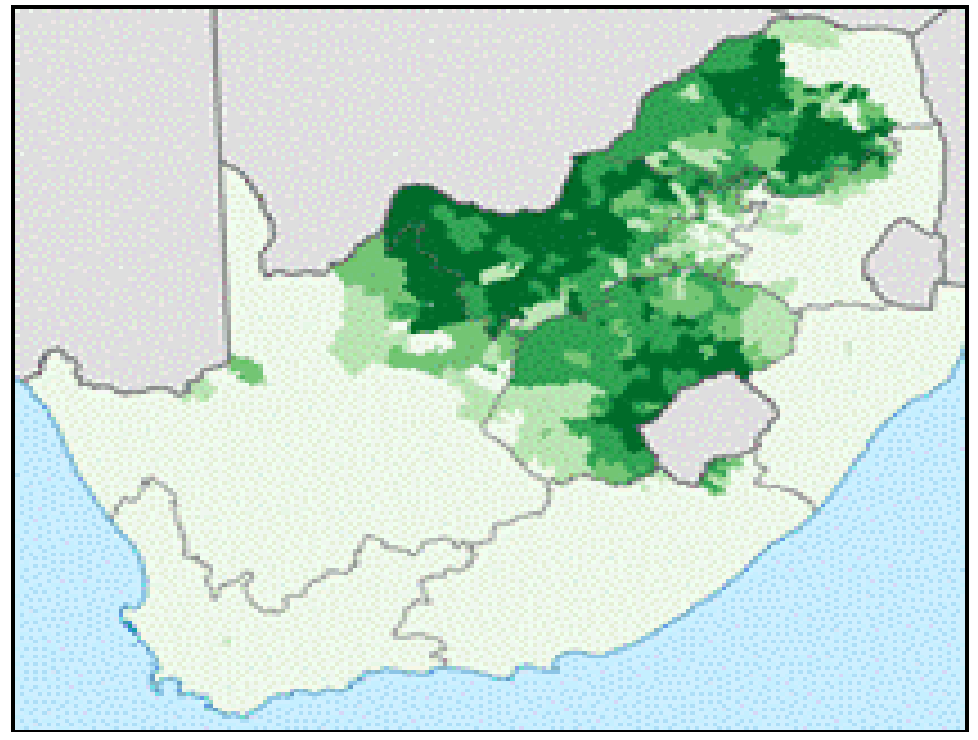

Figure 1: Sotho-Tswana language map, South Africa. Source: from the 2011 census broken down toward level. Available at https://en.wikipedia.org/wiki/Sotho-Tswana_peoples\#/media/File:South_Africa_2011_SothoTswana_speakers_proportion_map.svg

The darker shaded area on the map represents $80-100 \%$ coverage of people who speak a Sotho-Tswana language at home, with the lightest area representing 0-20\%. Despite the widespread coverage of the Sotho-Tswana language in central and northern South Africa, there are no precise indicators of how makgoma influences treatment seeking practices among traditionalists living with HIV in that area, but the map does go some way to demonstrate the potential impact of the unintended consequences in those provinces.

\section{From action themes to social practices using partic- ipatory action research}

In phase one axial coding - the identification of core themes during a grounded theory analysis ${ }^{33}$ — was used to establish; (1) the principle themes that had emerged 
during phase one (makgoma and medical pluralism), and (2) the action themes for phase two. The three action themes that were identified include: the 'origins of HIV', the 'viral load' and HIV being a 'chronic disease — not a death sentence"1. In order to transform the conceptual action themes into social practices, the Education and Awareness Department integrated the action themes into their existing outreach programmes.

The participatory action research was undertaken with six support groups for people living with HIV. The objectives of the support groups include; (1) assisting newly diagnosed HIV positive people to make a transition to living healthily with HIV once they know the status; (2) reinforce the importance of long term adherence to ART; (3) emphasise the importance of negotiating HIV disclosure; (4) reinforcing the importance of safe sexual practices, and (5) reducing HIV related stigma. Many of the people within these support groups are influenced by traditional value systems.

The action themes were integrated into the out-reach work in the following ways. The 'origins of HIV' action theme was integrated using narrative techniques that explain the biomedical version of events which enabled the zoonotic emergence of HIV-1 from simian acquired immunodeficiency (SIV) - for further information about HIV and zoonosis, see Sharp \& Hahn, 2011 ${ }^{34}$. The 'viral load' and 'HIV being transformed from a death sentence to a chronic disease' themes were integrated using narrative techniques and supplementary materials to explain the relevance of the viral load to wellness and why HIV can be transformed into a chronic disease by adhering to ART. These three action themes formed the core of a new educational heuristic that was designed by the partnership in order to develop a strategy to reduce non-adherence to ART among traditionalists living with HIV. The outputs from the first round of implementation were investigated in late 2016 and analysed in the first quarters of 2017.

\section{Method}

\section{Ethics approval}

All research ethical protocols were observed whilst conducting the study. Prior to data collection, permission for ethical clearance was obtained from the Turfloop Research and Ethics Committee (TREC), University of Limpopo. The participants were assured of their anonymity and confidentiality before both written and verbal consent was obtained prior to the group discussions.

\section{Study setting}

Two support groups agreed to participate in data collection. Both of the support groups are situated in a remote, deep rural area called Mokamole in the Mogalakwena Municipality, Waterberg district. Waterberg district is situated in the North West of South Africa - bordering with Botswana. It is estimated that the gini-coefficient in Waterberg district is 0.67 (the national South African gini-coefficent is 0.7 ) and this high level of inequality influences multiple spheres of day to day life for the majority of the population ${ }^{35}$. It is also estimated that just under $30 \%$ of women attending an antenatal clinic in the district are HIV positive ${ }^{36}$.

\section{Study design and data collection}

Five face-to-face, dual moderated, semi-structured homogenous group discussions of approximately one and a half hour duration were undertaken. The purpose of the group discussions was to elicit relational insights into the functioning and effectiveness of the action themes that were developed into educational heuristics during the phase of the research that is being reported on.

The group discussion method was favoured over focus group discussions because (1) the members of the support groups knew each other prior to the discussions (focus group discussions are typically between people who have not met before); (2) homogeneous groups are comprised of members who are 'comparable in the essential dimensions related to the research question and have a similar background, ${ }^{37: 196}$ and (3) the group discussion method enables qualitative data collection that corresponds with 'the way in which opinions are produced, expressed, and exchanged in everyday life $\mathrm{l}^{37: 197}$.

Each discussion group comprised of ten, mixed gender participants. The participants were purposefully sampled from support groups for people living with HIV which WWS was working with. The selection criteria were that they (1) were aged 18 years or more and (2) had been a member of a support group for two years or more. The group discussions used a combination of local languages (Sotho-Tswana) and English. The topic guide that was used during the group discussions included (1) the influence of traditionalism within their communities; (2) the influence of makgoma in the context of HIV; (3) the way in which the three action themes had influenced the discussion group participants' treatment seeking practices, and (4) an open session for additional comments. 


\section{Data analysis}

The group discussions were recorded and then transcribed verbatim, translated into English and back translated. The data were then analysed using selective coding, followed by a second round of theoretical coding and captured using Nvivo $10^{38}$. Selective coding is a component of grounded theory that typically follows axial coding. In order to ensure continuity with Phase One (axial coding and the identification of core themes) the transcripts from the group discussions in Phase Two were analysed using selective coding to refine the relational connections within the action themes as they became transformed into social practices by the support group membership. The selective codes were then 'theoretically' ${ }^{39}$ re-coded in order to develop a more coherent overview of how the action themes had influenced the participants' treatment seeking practices.

\section{Findings}

\section{Selective coding}

The selective coding, Table 1, was designed to situate the relevance of the action themes within the broader context of the participants' lifeworlds. The narratives indicated that:

(1) Traditionalism was considered to be common in the communities within which the participants live:

'Our people believe in tradition even though times have changed.

(2) Some traditionalists deny HIV exists and ascribe the symptoms of HIV related co-infections with symptoms associated with makgoma:

'People still don't believe HIV exists. They think we have dirty blood [makgoma] and we need a good traditional healer to treat us'.

And (3) the similarities between the symptoms of HIV related co-infections and makgoma generate confusions that can contribute to delays in testing and non-adherence to ART.

'They [people in the community] claim that in our tradition there is makgoma - not HIV. This causes a lot of confusion because some people do not want to go for a test and even stop taking treatment.

\section{Theoretical coding}

The theoretical coding, Table 1, provides indicators that the 'origins of HIV' action theme enabled support group members to develop trust that the biomedical account which explains the 'origins of HIV' through zoonosis is a legitimate argument.

'Now I know it [the symptom] is not caused by makgoma because it comes from a different place, I have the power to manage HIV.

The other two action themes - 'the 'viral load' and HIV being a 'chronic condition, not a death sentence' — act as reinforcing heuristics that provide further justification for the participants about why ART is a legitimate treatment seeking practice for people that are living with HIV.

'By keeping the viral load down with medication from the clinic and we can live with HIV in a bealthy way for a long time'.

'HIV is something that can be managed, like high bloods [bypertension]. It helps me to adhere'.

The theoretical coding also suggests that the action themes have contributed to reducing internalised stigma - but the underlying factors that could explain this in more detail are ambiguous.

'We now live normal lives. We openly come to support group sessions without any fear like before'.

Notwithstanding a reduction in internalised stigma, stigma from the broader community remained.

'They [community and/ or family members] still say we have neglected the traditional ways and now we are being punished for that'.

The stigma that was was discussed related to stigma that is associated with breaking traditional codes of conduct; not to HIV related stigma - which provides an indirect indicator of the broader societal obfuscation of the symptoms of HIV related co-infections and makgoma.

An unexpected finding was the emergence of a localised innovation among one support group to compete to determine who can maintain the lowest viral load.

'We look healthy because we now compete on who takes his or her medication better and the nurses monitor our progress. 
Table 1: findings from the selective and theoretical coding

\begin{tabular}{|c|c|}
\hline Selectivelycoded theme & Narrative examples \\
\hline $\begin{array}{l}\text { Traditionalist beliefs in the } \\
\text { community are strong }(n=17)\end{array}$ & $\begin{array}{l}\text { - Even if we can repeat ten times what is HIV, people believe what they believe. They can even } \\
\text { fight you for trying to make them listen to information about HIV. } \\
\text { - Our people believe in tradition even though times have changed. }\end{array}$ \\
\hline $\begin{array}{l}\text { Traditionalist beliefs in the } \\
\text { community ascribes symptoms } \\
\text { associated with HIV related co- } \\
\text { infections with makgoma }(n=16)\end{array}$ & $\begin{array}{l}\text { - People still don't believe HIV exists. They think we have dirty blood [makgoma] and we need } \\
\text { a good traditional healer to treat us. } \\
\text { - They [the community] do not believe it [HIV] is a chronic disease that must be treated every } \\
\text { day. Instead they go to a traditional healer for treatments because they confuse it with } \\
\text { makgoma. }\end{array}$ \\
\hline $\begin{array}{l}\text { The traditionalist belief in } \\
\text { makgoma adversely influences } \\
\text { initiation and adherence to ART } \\
(n=26)\end{array}$ & $\begin{array}{l}\text { - They [people in the community] claim that in our tradition there is makgoma - not HIV. This } \\
\text { causes a lot of confusion because some people do not want to go for a test and even stop taking } \\
\text { treatment. } \\
\text { - People use traditional medicine instead their [antiretroviral] medicine. Then they get too weak. } \\
\text { If you are too weak it takes long for antiretroviral medication to work when you start again. }\end{array}$ \\
\hline Theoretical coding & Narrative examples \\
\hline $\begin{array}{l}\text { Awareness that the origin of HIV } \\
\text { and makgoma is different } \\
\text { represents a bifurcation between } \\
\text { the earlier confusion about } \\
\text { symptoms }(n=28)\end{array}$ & $\begin{array}{l}\text { - Now I know it [the symptom] is not caused by makgoma because it comes from a different } \\
\text { place, I have the power to manage HIV. } \\
\text { - Now I know where HIV comes from. It helps me to see HIV so differently to makgoma. }\end{array}$ \\
\hline $\begin{array}{l}\text { The viral load and awareness } \\
\text { that HIV is now a chronic } \\
\text { disease reinforces the opening } \\
\text { that the 'origins' represents }(n= \\
\text { 22) }\end{array}$ & $\begin{array}{l}\text { - By keeping the viral load down with medication from the clinic and live with HIV in a healthy } \\
\text { way for a long time. } \\
\text { - HIV is something that can be managed, like high bloods [hypertension]. It helps me to adhere. }\end{array}$ \\
\hline $\begin{array}{l}\text { Self-reported increase in } \\
\text { adherence }(n=16)\end{array}$ & $\begin{array}{l}\text { - It is easy to adhere now we have learnt we have to keep the viral load down. } \\
\text { - Nurses have changed their attitude towards us because we no longer miss our clinic } \\
\text { appointments. } \\
\text { - I will never do that mistake of coming to the clinic late again because of believing it [HIV] is } \\
\text { makgoma and stopping my medication. }\end{array}$ \\
\hline $\begin{array}{l}\text { Stigma changes }- \text { but the } \\
\text { underlying reasons are } \\
\text { ambiguous }(n=7)\end{array}$ & $\begin{array}{l}\text { - We were not taking our medication openly because we were scared of what other people will } \\
\text { say about us. } \\
\text { - We now live normal lives. We openly come to support group sessions without any fear like } \\
\text { before. }\end{array}$ \\
\hline $\begin{array}{l}\text { Stigma from some parts of the } \\
\text { community exist }(n=12)\end{array}$ & $\begin{array}{l}\text { - They [community and/or family members] still say we have neglected the traditional ways and } \\
\text { now we are being punished for that. }\end{array}$ \\
\hline $\begin{array}{l}\text { Innovation: the Lesedi support } \\
\text { group begun a competition to } \\
\text { see which support group } \\
\text { member can maintain the lowest } \\
\text { viral load }(n=3)\end{array}$ & $\begin{array}{l}\text { - We look healthy because we now compete on who takes his or her medication better and the } \\
\text { nurses monitor our progress. } \\
\text { - No one will default because they know it is their commitment as a member of the support } \\
\text { group. }\end{array}$ \\
\hline
\end{tabular}

These findings are discussed in more detail in the section below.

\section{Discussion}

The selective coding indicates that there is tension within the broader community about the legitimacy of the biomedical explanation about the origins - zoonosis - of the symptoms associated with HIV-related co-infections. The tension is situated among two oppositional beliefs about the origins of the symptoms. On the one hand, traditionalists believe that the origins of the symptoms emerges from makgoma ('dirty blood') and the logical treatment seeking pathway is a traditional healer who can prescribe cleansing rituals to ameliorate the symptoms. On the other hand, the support group membership now attributes the origins of the symptoms to the biomedical explanation that the symptoms emerge from the HIV virus and the logical treatment seeking pathway is adherence to ART.

Whilst the 'origins of HIV' is the core of the support 
groups' counter explanation, the other action themes provide legitimising narratives that reinforces to the traditional beliefs relating to makgoma the biomedical explanation about the origins of HIV. The combination of the three action themes - as well as the effectiveness of the medication - thus contributes to the self-reported increase in adherence to ART and a reduction in internalised stigma among support group members. The combination of the selective and theoretical coding enables broader abstractions that relate to makgoma, treatment seeking practices and internalised stigma.

\section{Makgoma}

Findings from the group discussions indicate that the concept of makgoma is a co-factor that used to adversely influence adherence to ART amongst people living with HIV who are members of the support groups. These finding correspond with both local ${ }^{15}$ and internation$\mathrm{al}^{13}$ findings that indicate traditionalism can contribute to delays in testing and/or treatment interruption. The findings also indicate that the development of the three action themes into an educational heuristic by the Education and Awareness Department has enabled a bio-social counter narrative relating to HIV to emerge alongside the traditionalist discourse relating to makgoma. This emer- gent counter narrative is now provisioning members of the support groups with confidence about the legitimacy of ART. By default, the educational heuristic that has being developed problematises disease causation. As far as the authors are aware, the effect of altering the way in which disease causation influences treatment seeking practices is a novel finding that has not been documented in peer reviewed manuscripts relating to HIV and AIDS.

\section{Treatment seeking practices and disease causation}

In the context of the support groups, by problematising disease causation using the 'origins of HIV' heuristic — zoonosis or ritual defilement — has enabled the participants to re-define what was previously an ambiguous decision making space that conflated makgoma/ ritual defilement with a HIV co-infection. The 'origins of HIV' action theme enables the problematisation of the ambiguous decision making space and the other two action themes - the 'viral load' and HIV being a 'chronic condition, not a death sentence' — act as reinforcing narratives.

For the village support group membership there is now a clearly defined metaphorical boundary between symptoms that used to simultaneously be associated with both makgoma/ritual defilement and HIV related co-infections , Figure 2. 

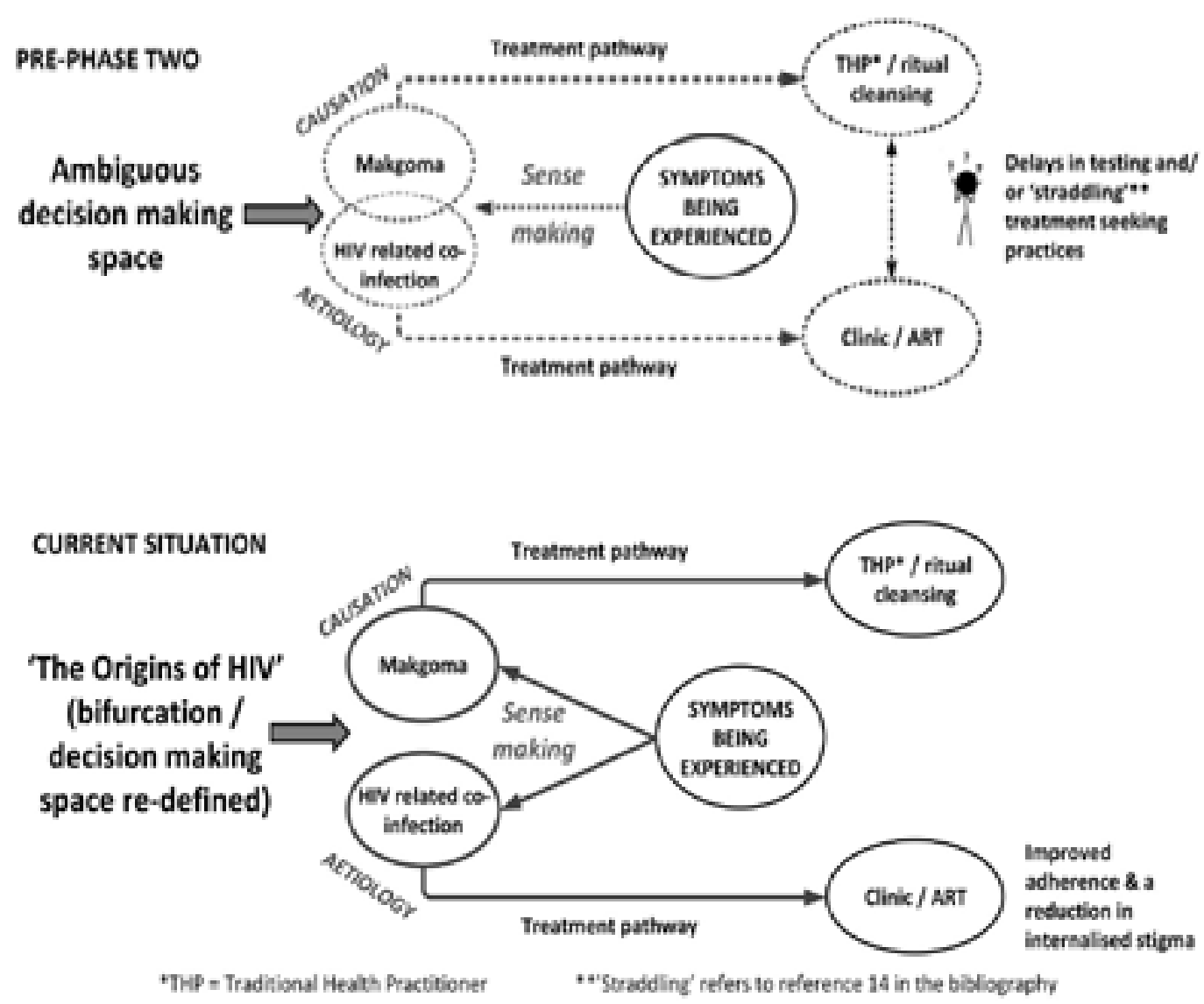

Figure 2: Boundary differentiation with regard to disease causation and subsequent treatment seeking practices among the support group membership

The metaphorical boundary serves to demarcate a distinction between makgoma/ritual defilement and HIV related co-infections as different causes of similar symptoms. In turn, this makes the retrospective sense making that identifies disease causation, followed by the subsequent treatment seeking decision making process, more intentional because the support group membership now accepts — and responds to - the biomedical logic that justifies adherence to ART. The metaphorical boundary demarcation relating to symptom causation represents a bifurcation point from which confidence has developed that HIV (1) exists; (2) is qualitatively different to makgoma/ritual defilement, and (3) requires treatment using ART, not ritual cleansing.

\section{Internalised stigma}

There is evidence from the participants' narratives that the boundary demarcation has also enabled a reduction in internalised stigma. As far as the authors are aware, this is also a novel finding that has not been reported on before. The internalised stigma that was discussed related to makgoma, not HIV. There is logic behind this because makgoma is a 'cultural taboo'31:942 that should be rectified through ritual cleansing. Differentiating between disease causation enables cognisance that any taboos associated with not seeking appropriate ritual cleansing/s to treat makgoma become an obsolete concern for the support group members because they are aware that HIV is the cause the symptoms, not makgoma. However, the discussions were limited so it is not possible to provide any further comment on this.

\section{Policy implications}

The 'origins of HIV' has been identified as a co-factor that adversely affects HIV related treatment seeking practices since $2004^{40}$. Despite awareness of this phenomenon, there has been no documented strategy to counter the unintended consequences of the conflated treatment seeking decision making process that some traditionalists have when confronted with makgoma/ritual defilement and/or a HIV co-infection. The community-university partnership has developed a strategy that enables traditionalists living with HIV to differentiate between symptom causation which has subsequent, beneficent effects 
on treatment seeking practices and wellness, including increased adherence and — unintentionally — reducing internalised stigma. Increasing adherence to ART and stigma reduction are both priority areas in the draft National Strategic Plan on HIV, STIs and TB 2017-2022 (NSP) ${ }^{8}$.

Replicating this approach may be an opportunity that could contribute to improving adherence to ART among traditionalists living with HIV. The strategy is especially relevant in Limpopo Province because (1) the Sotho-Tswana languages are spoken throughout the province and (2) SANAC has documented how non-adherence in Limpopo is attributed to high levels of traditional, or alternative, medicine use.

\section{Limitations and further research}

There are two limitations. The first is that grounded theory does not require validation and the findings reflect the experiences and opinions of a small sample in Waterberg district. The second limitation is that the findings are self-reported. Self-reported findings should be treated with caution because the reporting may be biased by the accuracy of the details that are recalled by the respondents, social desirability and confusion/s about the questions being asked.. These limitations indicate that further research is required to validate the findings.

\section{Conclusion}

It has been demonstrated that a concept which Sotho-Tswana speaking traditionalists call makgoma is a co-factor which can adversely influence adherence to ART. The associated literature reveals that, to date, there are no reports of strategies that have been designed to counter the influence. The findings suggest that both increased adherence to ART and the reduction in internalised stigma are enabled by a counter narrative to the traditionalist discourse that conflates HIV related co-infections with makgoma - or denies the existence of HIV. The counter narrative marks a point of departure from the traditionalist discourse, with the bifurcation point being symptom causation. The counter narrative enables a biomedical explanation about how HIV came into existence (zoonosis) which was not known about by the support groups' membership prior to the 'origins of HIV' action theme being introduced.

The combination of the 'origins of HIV' action theme — reinforced by the 'viral load' and HIV being a 'chronic condition, not a death sentence' action themes - represent a heuristic that justifies adhering to ART among traditionalists living with HIV. Whilst the findings are localised, the implications may represent an opportunity to develop an innovative strategy that makes sense to Sotho-Tswana speakers to (1) increase adherence to ART and reduce internalised stigma among traditionalists living with HIV, and (2) may possibly be a start point to develop strategies to improve testing among the same language group.

\section{Conflict of interest}

Authors have no competing interests to declare.

\section{References}

1. Burman CJ, Aphane M. Community viral load management: can 'attractors' contribute to developing an improved bio-social response to HIV risk-reduction? Nonlinear Dynamics, Psychology, and Life Sciences; 2016; 20: 81-116.

2. WWS. Waterberg Welfare Society [internet]. 2017. [Updated 2016 September 23]. Available from http://www. waterbergwelfaresociety.org.za/.

3. Teeraananchai S, Kerr SJ, Amin J, Ruxrungtham K, Law MG. Life expectancy of HIV-positive people after starting combination antiretroviral therapy: a meta-analysis. HIV Med: (2016, accessed 2017, 31 August).

4. Rodger A, Bruun T, Cambiano V. HIV transmission risk through condomless sex if $\mathrm{HIV}+$ partner on suppressive ART: PARTNER study: $21^{\text {st }}$ Conference on Retroviruses and Opportunistic Infections, 2014 March 3-6; Boston, USA.

5. Baggaley R, Dalal S, Johnson C, Macdonald V, Mameletzis I, Rodolph M, et al. Beyond the 90-90-90: refocusing HIV prevention as part of the global HIV response. J Int AIDS Soc; 2016; 19: 21348.

6. SANAC. Let Our Actions Count: Reflections on NSP 2012-2016 and moving forward to NSP 2017-2022. Pretoria. 2016, p. 34. Available at http:// sanac.org.za/wp-content/uploads/2017/01/Final-NSP-Document.pdf.

7. Steegen K, Carmona S, Bronze M, Papathanasopoulos MA, van Zyl G, Goedhals D, et al. Moderate Levels of Pre-Treatment HIV-1 Antiretroviral Drug Resistance Detected in the First South African National Survey. PloS One; 2016; 11: e0166305.

8. SANAC. The South African National Strategic Plan for HIV, TB and STIs 2017-2022. Pretoria. 2017, p. 
109. Available at http://sanac.org.za/wp-content/uploads/2017/05/NSP_FullDocument_FINAL.pdf.

9. Kerrigan D, Kennedy CE, Morgan-Thomas R, Reza-Paul S, Mwangi P, Win KT, et al. A community empowerment approach to the HIV response among sex workers: effectiveness, challenges, and considerations for implementation and scale-up. The Lancet, 2015; 385: 17285.

10. Shannon K, Strathdee SA, Goldenberg SM, Duff P, Mwangi P, Rusakova M, et al. Global epidemiology of HIV among female sex workers: influence of structural determinants. The Lancet, 2014; 385: 55-71.

11. Wouters E, Masquillier C, Ponnet K, le Roux Booysen F. A peer adherence support intervention to improve the antiretroviral treatment outcomes of HIV patients in South Africa: the moderating role of family dynamics. Soc Sci Med; 2014; 113: 145-53.

12. Orr N, Hajiyiannis H, Myers L, Makhubele MB, Matekane T, Delate $\mathrm{R}$, et al. Development of a $\mathrm{Na}$ tional Campaign Addressing South African Men's Fears About HIV Counseling and Testing and Antiretroviral Treatment. J Acquir Immune Defic Syndr, 2017; 74 Suppl 1: S69-S73.

13. Flores D, Leblanc N, Barroso J. Enroling and retaining human immunodeficiency virus (HIV) patients in their care: A metasynthesis of qualitative studies. Int J Nurs Stud; 2016; 62: 126-36.

14. Moshabela M, Bukenya D, Darong G, Wamoyi J, McLean E, Skovdal M, et al. Traditional healers, faith healers and medical practitioners: the contribution of medical pluralism to bottlenecks along the cascade of care for HIV/AIDS in Eastern and Southern Africa. Sex Transm Infect. 93: (2017, accessed 2017, 28 August).

15. Pantelic M, Cluver L, Boyes M, Toska E, Kuo C, Moshabela M. Medical pluralism predicts non-ART use among parents in need of ART: a community survey in KwaZulu-Natal, South Africa. AIDS Behav; 2015; 19: $137-44$.

16. SANAC. Enhanced Progress Report: National Strategic Plan on HIV, STIs and TB (2012-2016). Pretoria. 2016, p. 134. Available at http://sanac.org.za/wp-content/uploads/2016/07/EPR-SANAC-NEW-DOC-latest-update3.pdf.

17. WHO. Traditional Medicine Strategy 2002-2005. Geneva. World Health Organization, 2002. Available at http:/ / www.wpro.who.int/health_technology/book_ who_traditional_medicine_strategy_2002_2005.pdf.
18. Rankoana SA. The use of indigenous knowledge for primary health care among the Northern Sotho in the Limpopo Province. Department of Sociology. South Africa: University of Limpopo, 2012, p. 251.

19. Friend-du Preez N, Peltzer K. HIV symptoms and health-related quality of life prior to initiation of HAART in a sample of HIV-positive South Africans. AIDS Behav; 2010; 14: 1437-47.

20. Street RA. Unpacking the new proposed regulations for South African traditional health practitioners. $S$ Afr Med J; 2016; 106: 22-3.

21. Zuma T, Wight D, Rochat T and Moshabela M. The role of traditional health practitioners in Rural KwaZulu-Natal, South Africa: generic or mode specific? BMC Complementary and Alternative Medicine; 2016; 16: 304.

22. McFarlane C. South Africa: The rise of traditional medicine. Insight on Africa; 2015; 7: 60-70.

23. Leclerc-Madlala S, Green E, Hallin M. Traditional healers and the "Fast-Track" HIV response: is success possible without them? Afr J AIDS Res; 2016; 15: 185-93. 24. Dubois R. The Mirage of Health: Utopias, Progress and Biological Change. New York: Anchor Books, 1961. 25. Ibeneme S, Eni G, Ezuma A, Fortwengel G. Roads to Health in Developing Countries: Understanding the Intersection of Culture and Healing. Current Therapeutic Research; 2017: 13-18.

26. Niehaus I, Jonsson G. Dr. Wouter Basson, Americans, and wild beasts: men's conspiracy theories of HIV/ AIDS in the South African Lowveld. Med Anthropol; 2005; 24: 179-208.

27. Kuhanen J. 'No sex until marriage!': moralism, politics and the realities of HIV prevention in Uganda, 19861996. Journal of Eastern African Studies; 2015; 9: 270-88.

28. Makgahlela MW and Sodi T. Cultural conceptions of a bereavement-related illness in a South African indigenous community. Journal of Psychology in Africa; 2016; 26: 541-5.

29. Mönnig HO. The Pedi. Pretoria: J.L. Van Schaik, 1978. 30. Niehaus I. Averting danger: taboos and bodily substances in the South African lowveld. Critical African Studies; 2013; 5: 127-39.

31. Shirindi M, Makofane M. Ritual impurities: perspectives of women living with HIV and AIDS. African Journal for Physical, Health Education, Recreation and Dance; 2015; 21: 941-52.

32. Disetlhe K. The curse of being a nyatsi - lover's blood also needs to be cleansed. The Sowetan. 2014, November 
8. [Updated 2017 September 12]. Available from http:// www.sowetanlive.co.za/entertainment/2014/11/08/thecurse-of-being-a-nyatsi---lover-s-blood-also-needs-to-becleansed.

33. Strauss A, Corbin J. Basics of qualitative research techniques. Thousand Oaks, CA: Sage publications, 1998. 34. Sharp PM and Hahn BH. Origins of HIV and the AIDS pandemic. Cold Spring Harbor Perspect in Medicine 1: a006841 (2011, accessed 22 September 2015).

35. Marcatelli M. Suspended redistribution: 'green economy' and water inequality in the Waterberg, South Africa. Third World Quarterly; 2015; 36: 2244-58.

36. Shisana O, Rehle T, Simbayi L, Zuma K, Jooste S, Zu- ngu N, et al. South African National HIV Prevalence, Incidence and Behaviour Survey, 2012. Cape Town: HSRC Press, 2014.

37. Flick U. An introduction to qualitative research. $4^{\text {th }}$ Edition ed. London: Sage Publications, 2009.

38. Glaser BG and Strauss AL. The discovery of grounded theory: Strategies for qualitative research. New Jersey: Transaction Publishers, 2009.

39. Glaser BG. Doing grounded theory: Issues and discussions. Mill Valley: Sociology Press, 1998.

40. Kalichman SC, Simbayi L. Traditional beliefs about the cause of AIDS and AIDS-related stigma in South Africa. AIDS Care; 2004; 16: 572-80. 